\title{
Asthma mortality in Russia between 1980 and 1989
}

\author{
R.G. Oganov, G.Ya. Maslennikova
}

\begin{abstract}
Asthma mortality in Russia between 1980 and 1989. R.G. Oganov, G.Ya. Maslennikova. (C) ERS Journals Ltd 1999.

ABSTRACT: There is evidence that mortality due to asthma has increased in a number of nations over the last two decades. This study was conducted to assess asthma mortality rates in Russia from 1980 to 1989. Data obtained were compared with figures from other countries.

National asthma deaths were obtained from the Ministry of Health of the Russian Federation. Age- and sex-specific rates per 100,000 population per year were adjusted to the European population. Annual changes in mortality rates for the study period were estimated by linear regression analysis.

Between 1980 and 1989 , asthma mortality rates per 100,000 population per year increased from 3.7 to 5.3 in the total Russian population. Differences according to age and sex were observed. Asthma deaths increased with age and in most cases males showed higher death rates than females. There was a statistically significant annual increase in mortality rates for young males $<5$ yrs of age and for adult males aged 35 $64 \mathrm{yrs}$, as well as for females aged $\geq 65$ yrs.

Asthma mortality rates in Russia between 1980 and 1989 may be considered moderate as compared with death rates reported for the same period in other countries. Eur Respir J 1999; 13: 287-289.
\end{abstract}

National Research Centre for Preventive Medicine of the Ministry of Health of the Russian Federation, Moscow, Russia.

Correspondence: R.G. Oganov

National Research Centre for Preventive Medicine of the Ministry of Health of the Russian Federation

10 Petroverigsky Street

101953 Moscow

Russia

Fax: 70959239384

Keywords: Adults

asthma

mortality

youth

Received: May 141997

Accepted after revision October 51998
Over the last two decades, there has been a worldwide increase in mortality [1-8] and morbidity rates [1, 5-7, 918] for asthma. These changes have been particularly noticeable among children and young people $[3,4,7-10,12$, $14,17,19]$ and subjects with low income [1]. Possible reasons for a rise in asthma mortality and morbidity include underestimation of the severity of asthma symptoms [4, a14, 16, 17, 20], inadequate treatment of the acute exacerbation episodes [3, 19, 21, 22], absence or deficiency of long-term appropriate pharmacological care for the prevention of asthma symptoms, and progressive deterioration of the patient's condition [19, 21-24]. In order to reduce asthma mortality and morbidity, new methods for the diagnosis, treatment, and prevention of the disease have recently been recommended for both patients and healthcare providers [25-27].

Data on asthma death rates for Russia have never been reported in the European Community Atlas of Avoidable Death. Therefore, this study was conducted to assess asthma mortality rates in Russia from 1980 to 1989 and to compare the results obtained with figures from other countries.

\section{Methods}

Primary data on asthma mortality in Russia were obtained from death certificates in which asthma was recorded as the "underlying cause" of death. Death certificates were initially collected and classified by age and sex by the Russian Health Statistics Services. Final reporting forms were submitted to the Statistical Department of the Ministry of Health of the Russian Federation (SDMHRF). Data on asthma mortality for each year from 1980 to 1989 and individualized by age and sex were then provided by the SDMHRF to the National Research Center for Preventive Medicine, which was the institution responsible for the study. Intercensal population estimates for each year of the study period were also obtained from the SDMHRF.

Asthma mortality is expressed as death rates or number of deaths per 100,000 population per year for the whole Russian population. Annual death rates stratified by age and sex were also calculated. These figures were standardized by the direct method with the European and worldwide population [28], as well as with the Russian population in 1980. The group distribution in the reference populations was the same as in the study population. Asthma death rates were classified according to the International Classification of Diseases (9th revision, clinical modification code 493) [29].

To estimate annual changes in asthma death rates from 1980 to 1989 , a linear regression model was used [30]. Changes observed during the study period were analysed with the Student's t-test.

\section{Results}

Asthma death rates per 100,000 population per year from 1980 through 1989, adjusted by age and sex to the European population are shown in table 1. Asthma death rates in the study population varied from year-to-year but were found to be related to sex and age. In all age groups, except in young people aged 5-34 yrs, males had higher mortality rates than females. In contrast, death rates were higher in females than in males among the young population. An increase in death rates with age was also found. In children of $<5$ yrs of age, death rates were the lowest as compared with the other age groups. They did not exceed 0.12 per 100,000 population per year during the whole study period. In the young, the estimates of asthma death rates were around 0.5 per 100,000 population per year. Those rates were more than seven times lower than death 
Table 1. - Age- and sex-specific death rates for asthma per 100,000 population per year*

\begin{tabular}{|c|c|c|c|c|c|c|}
\hline \multirow[b]{2}{*}{ Year } & \multirow[b]{2}{*}{ Sex } & \multicolumn{5}{|c|}{ Age yrs } \\
\hline & & $0-4$ & $5-34$ & $35-64$ & $>65$ & All \\
\hline \multirow{3}{*}{1980} & Male & 0.04 & 0.46 & 5.31 & 30.24 & 5.59 \\
\hline & Female & 0.08 & 0.42 & 3.64 & 15.46 & 3.30 \\
\hline & Both sexes & 0.06 & 0.44 & 4.24 & 19.13 & 3.95 \\
\hline \multirow[t]{3}{*}{1981} & Male & 0.04 & 0.35 & 5.64 & 27.10 & 5.33 \\
\hline & Female & 0.02 & 0.46 & 3.62 & 14.86 & 3.24 \\
\hline & Both sexes & 0.03 & 0.41 & 4.38 & 18.03 & 3.86 \\
\hline \multirow[t]{3}{*}{1982} & Male & 0.06 & 0.48 & 5.60 & 26.73 & 5.33 \\
\hline & Female & 0.04 & 0.49 & 3.80 & 14.02 & 3.23 \\
\hline & Both sexes & 0.05 & 0.49 & 4.47 & 17.31 & 3.85 \\
\hline \multirow[t]{3}{*}{1983} & Male & 0.05 & 0.53 & 5.52 & 26.55 & 5.30 \\
\hline & Female & 0.09 & 0.52 & 3.83 & 15.01 & 3.37 \\
\hline & Both sexes & 0.07 & 0.53 & 4.45 & 18.03 & 3.95 \\
\hline \multirow[t]{3}{*}{1984} & Male & 0.09 & 0.49 & 6.18 & 27.66 & 5.66 \\
\hline & Female & 0.02 & 0.56 & 3.95 & 15.75 & 3.51 \\
\hline & Both sexes & 0.05 & 0.52 & 4.80 & 18.86 & 4.17 \\
\hline \multirow[t]{3}{*}{1985} & Male & 0.05 & 0.35 & 6.06 & 29.42 & 5.75 \\
\hline & Female & 0.04 & 0.44 & 4.27 & 16.66 & 3.69 \\
\hline & Both sexes & 0.04 & 0.39 & 4.93 & 20.00 & 4.29 \\
\hline \multirow[t]{3}{*}{1986} & Male & 0.05 & 0.43 & 5.27 & 25.02 & 4.99 \\
\hline & Female & 0.03 & 0.46 & 3.51 & 14.55 & 3.16 \\
\hline & Both sexes & 0.04 & 0.44 & 4.19 & 17.28 & 3.72 \\
\hline \multirow[t]{3}{*}{1987} & Male & 0.08 & 0.34 & 5.97 & 27.20 & 5.47 \\
\hline & Female & 0.02 & 0.46 & 3.46 & 15.46 & 3.25 \\
\hline & Both sexes & 0.05 & 0.40 & 4.45 & 18.58 & 3.95 \\
\hline \multirow[t]{3}{*}{1988} & Male & 0.08 & 0.42 & 6.18 & 32.08 & 6.12 \\
\hline & Female & 0.03 & 0.46 & 3.90 & 17.54 & 3.65 \\
\hline & Both sexes & 0.06 & 0.44 & 4.84 & 21.20 & 4.41 \\
\hline \multirow[t]{3}{*}{1989} & Male & 0.10 & 0.50 & 7.53 & 38.55 & 7.39 \\
\hline & Female & 0.12 & 0.49 & 4.81 & 20.19 & 4.31 \\
\hline & Both sexes & 0.11 & 0.50 & 5.93 & 25.01 & 5.28 \\
\hline
\end{tabular}

*: death rates adjusted to the European population.

rates in the middle-aged population $35-64$ yrs. The highest death rates due to asthma, i.e., death rates $>14$ per 100,000 per population per year, were found in people aged $\geq 65$ yrs

There were statistically significant $(\mathrm{p}<0.05)$ annual increases in mortality rates for asthma per 100,000 population in the total population ( 0.1 annual increase), in young males $<5$ yrs of age ( 0.005 annual increase), in males aged $35-64$ yrs ( 0.15 annual increase), and in females $\geq 65$ yrs ( 0.4 annual increase). In the remaining age and sex groups, annual changes in mortality rates were either not significant or close to zero.

\section{Discussion}

The present study provides data on asthma mortality rates in the Russian population for the period 1980-1989 in different age and sex groups after adjustment to the European population distributed to the same age groups. The use of the other reference populations such as the Russian population in 1980 or worldwide population did not substantially modify asthma death rates as compared with rates adjusted by age and sex to the European population. A slight difference in the death rates resulting from the different adjustments was observed in elderly people only.

Between 1980 and 1989, asthma mortality rates for the total Russian population increased from 3.7 to 5.3 per 100,000 population per year. These figures are higher than corresponding asthma mortality rates in the overall population of the USA [5-7] and France [21], but lower than in New Zealand [19]. Since the "accuracy" of asthma diagnosis reaches $95 \%$ in the population of $<35$ yrs of age [31], most reports include asthma mortality rates for these age groups. In the Russian population aged 5-34 yrs, annual asthma mortality rates were around 0.5 per 100,000 population per year. These figures are higher than mortality rates for this age group in the USA [4], very close to those in Canada [16], and lower than in New Zealand [24] or Australia [2]. Accordingly, asthma mortality rates found between 1980 and 1989 in Russia either in the total population or among young people may be considered as moderate in comparison with the death rate estimates for the corresponding populations in other countries.

The present study demonstrates that there is an increase in asthma mortality rates with age. Similar trends in asthma death rates have also been noted in the populations of other countries, such as the USA [1, 3, 5, 8], Canada $[16,32]$, France [21], and New Zealand [19]. The increase in asthma mortality rates with age is usually associated with the decline of certification accuracy $[3,5,8,19]$. The later decline takes place due to the difficulties in differentiation of asthma and other conditions, such as chronic obstructive pulmonary disease, in subjects of advanced age $[1,19,32]$. Other reasons for the higher mortality rates among older people are associated with inappropriate treatment of the disease or poor compliance with asthma treatment [8]. 
For the period 1980-1989, mortality for asthma increased in most countries [1-8]. According to an international report involving 14 countries [2], asthma deaths among the population aged 5-34 yrs have increased in 11 and decreased in 3 countries. In Canada [16], however, no changes were found in asthma death rates either in children aged $0-14$ yrs or in young adults aged 15-34 yrs. In Russia, asthma mortality rates showed a statistically significantly increase in the total population of both sexes. It is expected that this augmentation takes place due to the increase in asthma death rates among males aged $<5$ yrs and in populations of males or females aged $\geq 35$ yrs. By contrast, in the population aged 5-34 yrs, no changes in asthma death rates were found.

It has already been suggested that the increase in the prevalence of severe cases of asthma $[1,3,4,8,19,21$, $32]$ and an inappropriate treatment of the disease [1, 23, 24] may be the cause of either the high rates of asthma mortality or their rise during the study period. A study carried out in Moscow for the period 1989-1990 [33] has shown that bronchodilators, given orally, were the most common regimen for home asthma treatment in children during or between asthma attacks. This therapeutic approach is not consistent with a recently recommended treatment regimen [25-27]. Therefore, investigation of asthma morbidity and other factors related to asthma death rates or their changes in Russia seems of special interest. Acknowledgement. The authors would like to
express their appreciation to J.M. Anto for his
contribution to this work.

\section{References}

1. Evans R, Mullally DI, Wilson RW, et al. National trends in the morbidity and mortality of asthma in the US. Prevalence, hospitalization and death from asthma over two decades: 1965-1984. Chest 1987; 91: 65S-74S.

2. Jackson R, Sears MR, Beaglehole R, Rea HR. International trends in asthma mortality: 1970 to 1985 . Chest 1988; 94: 914-919.

3. Sly RM. Mortality from asthma in children 1979-1984. Ann Allergy 1988; 60: 433-443.

4. Weiss KB, Wagener DK. Changing patterns of asthma mortality. Identifying target populations at high risk. JAMA 1990; 264: 1683-1687.

5. Fulwood R, Parker S, Hurd SS. Asthma - United States, 1980-1987. MMWR 1990; 9: 494-496.

6. Anonymous. From the Centers for Disease Control: Asthma - United States, 1980-1990. JAMA 1992; 268: 1995-1999.

7. Lee P. Public Health Service. Healthy People 2000. Progress Report For: Environmental Health. U.S. Department of Health and Human Services, 1993.

8. Arrighi HM. US asthma mortality: 1941 to 1989. Ann Allergy Asthma Immunol 1995; 74: 321-326.

9. Carman PG, Landau LI. Increased pediatric admissions with asthma in Western Australia - a problem of diagnosis? Med J Aust 1990; 152: 23-26.

10. Ford RM. Asthma in Australia. Aust NZ J Med 1994; 24 : 71.

11. Fleming DM, Crombie DL. Prevalence of asthma and hay fever in England and Wales. Br Med J 1987; 294: 279283.

12. Bates DV, Baker-Anderson M. Asthma morbidity and mortality in Canada. J Allergy Clin Immunol 1987; 80: 395-398.

13. Burr ML, Butland BK, King S, Vaughan-Williams E.
Changes in asthma prevalence: two surveys 15 years apart. Arch Dis Child 1989; 64: 1452-1456.

14. Gergen PJ, Weiss KB. Changing patterns of asthma hospitalization among children: 1979 to 1987. JAMA 1990; 264: 1688-1692.

15. Burney PGJ, Chinn S, Rona RJ. Has the prevalence of asthma increased in children? Evidence from the National Study of Health and Growth 1973-86. Br Med J 1990; 300: $1306-1310$.

16. Wilkins K, Mao Y. Trends in rates of admission to hospital and death from asthma among children and young adults in Canada during the 1980s. Can Med Assoc $J$ 1993; 148: 185-190.

17. Hyndman SJ, Williams DRR, Merrill SL, Lipscombe JM, Palmer CR. Rates of admission to hospital for asthma. $\mathrm{Br}$ Med J 1994; 308: 1596-1600.

18. Anderson HR, Butland BK, Strachan DP. Trends in prevalence and severity of childhood asthma. Br Med $J$ 1994; 308: 1600-1604.

19. Sears MR, Beaglehole R. Asthma morbidity and mortality: New Zealand. J Allergy Clin Immunol 1987; 80: 383-388.

20. Anderson HR. Increase in hospital admissions for childhood asthma: trends in referral, severity, and readmissions from 1970 to 1985 in a health region of the United Kingdom. Thorax 1989; 44: 614-619.

21. Bousquet J, Hatton F, Godard P, Michel FB. Asthma mortality in France. J Allergy Clin Immunol 1987; 80: 389-394.

22. Morray B, Redding G. Factors associated with prolonged hospitalization of children with asthma. Arch Pediatr Adolesc Med 1995; 149: 276-279.

23. Bosco LA, Knapp DE, Gerstman B, Graham CF. Asthma drug therapy trends in the United States, 1972 to $1985 . J$ Allergy Clin Immunol 1987; 80: 398-402.

24. Pearce N, Beasley R, Crane J, Burgess C, Jackson R. End of the New Zealand asthma mortality epidemic. Lancet 1995; 345: 41-44.

25. National Heart, Lung, and Blood Institute. International Consensus Report on Diagnosis and Management of Asthma. NIH Publication 1992; No. 92-3091.

26. British Thoracic Society, British Paediatric Association, Research Unit of the Royal College of Physicians of London, King's Fund Centre, National Asthma Campaign, Royal College of General Practitioners in Asthma Group, British Association of Accident and Emergency Medicine, British Paediatric Respiratory Group. Guidelines on the Management of Asthma. Thorax 1993; 48: S1-S24.

27. Thoracic Society of Australia and New Zealand. Consensus on asthma: asthma management plan. NZ Med $J$ 1990; 103: 16-18.

28. Waterhouse J, Correa P, Muir C, Powell J, eds. Cancer Incidence in Five Countries. Lyon, IARC, 1976; p. 456.

29. International Classification of Diseases, 9th Revision, World Health Organization, Geneva, 1978.

30. Kleinbaum DG, Kupper LL, Muller KE, eds. Applied Regression Analysis and Other Multivariable Methods. 2nd ed. Boston, MA, PWS Publishers, 1988.

31. Subcommittee of the British Thoracic Association Research Committee. Accuracy of death certificate in bronchial asthma: accuracy of certification procedures during the confidential inquiry by the British Thoracic Association. Thorax 1984; 39: 505-509.

32. Guidotti TL, Jhangri GS. Mortality from airways disorders in Alberta, 1927-1987: an expanding epidemic of COPD, but asthma shows little change. J Asthma 1994; 31: 277-290.

33. Maslennikova GYa, Morosova ME, Salman NV, Kulikov SM, Oganov RG. Asthma education programme in Russia: educating patients. Patient Educ Counsel 1998; 33: $113-127$. 